Rolle. Wegen der Übersichtlichkeit und Radikalität bei der Entfernung eines Thymoms aber auch der zu fordernden ausgedehnten Thymektomie im Falle der Thymushyperplasie ist die mediane Sternotomie operativer Zugangsweg der Wahl. Für die Prognose ist der intraoperative Nachweis von invasivem Wachstum von entscheidender Bedeutung.

Schliisselwörter: Thymom - Thymushyperplasie - Computertomographie.

232. A. J. Weinreich, G. Silvay, J. B. Eisenkraft, A. Papatestos, New York: Transcervical Thymectomy in the Treatment of Myastenia gravis.

Manuskript nicht eingegangen

\title{
233. Wie lebensbedrohlich sind Thoraxstich- und -schußverletzungen
}

\author{
E. Fellmann, H. Wacha und K. Lüders \\ Krankenhaus Nordwest (Dir.: Professor Dr. E. Ungeheuer), Steinbacher Hohl 2-21, D-6000 Frankfurt/M.
}

\section{Life Threatening Gunshot and Knife Wounds of the Thorax}

Summary. We discuss our therapeutical proceeding in the management of 46 cases of gunshot and knife wounds of the thorax. We recommend conservative treatment as long as possible; immediate surgical intervention is indicated if additional trauma of the abdomen is visible or likely. The lethality is $4.35 \%$; in peacetime therefore prognosis seems good if the patients are in reach of a well organized and staffed clinic. The reasons for a good prognosis are the kind of weapon, an optimal transport system, how young the patients are, and the good control of patients by simple surgical means.

Key words: Gunshot and knife wounds of the thorax.

Zusammenfassung. An Hand von 46 Stich- und Schußverletzungen des Thorax stellen wir unser therapeutisches Vorgehen dar. Dieses ist bei reinen Thoraxverletzungen so lange wie möglich konservativ, während wir bei Mitverletzung des Abdomens sofort laparotomieren. Damit ergibt sich eine Letalität von 4,35\%, womit die Prognose in Friedenszeiten günstig zu sein scheint, falls diese Verletzten eine kompetente Klinik lebend erreichen. Gründe dafür sind u. a. 1. die Art d. Waffen, 2. das optimierte Rettungswesen, 3. das geringe Alter meist Organgesunder, 4. die gute Überwachbarkeit durch einfache chirurgische Maßnahmen.

Schliusselwörter: Thoraxstich- und -schußverletzungen.

\section{Bronchusabriß und primäre Bronchusanastomose}

\author{
M. Hentschel \\ Chirurgische Abteilung des Luisenhospitals Aachen, Akademisches Lehrkrankenhaus, \\ Boxgraben 95, D-5100 Aachen
}

\section{Complete Bronchus Rupture and Primary Bronchial Anastomosis}

Summary. We report on a 28 -year-old man who after a blunt thorax contusion developed protracted pneumothorax on the right and extensive cutaneous emphysema in the cervicothorax area. The tension of the pneumothorax was relieved by chest tube, which however did not remedy the atelectasis owing to loss of air by complete bronchus rupture. There were concomitant fractures of the clavicle, scapula, 1st to 5th ribs and right phrenic paresis. Primary bronchial anastomosis on day 4 after accident led to full pulmonary distension. Phrenic paresis continued for 9 months following accident.

Key words: Complete bronchus rupture - Phrenic nerve paresis - Clavicular fracture - Primary bronchial anastomosis.

Zusammenfassumg. Bericht über einen 28jährigen Mann, der nach stumpfer Thoraxquetschung protrahiert einen Spannungspneumothorax rechts und ein ausgedehntes Hautemphysem im Hals-Thoraxbereich ent- 